\title{
Dermatophagoides farinae Antigen IgE Antibody Measurement
}

National Cancer Institute

\section{Source}

National Cancer Institute. Dermatophagoides farinae Antigen IgE Antibody

Measurement. NCI Thesaurus. Code C130132.

A measurement of the Dermatophagoides farinae antigen IgE antibody in a biological specimen. 